\title{
Greek Inscriptions from Bahrain
}

\author{
Pierre-Louis GATIER*, Pierre LOMBARD** \& Khalid M. AL-SINDI*** \\ * Institut Fernand Courby, Maison de l'Orient Méditerranéen, Lyon, France. \\ ** Groupe de Recherches et d'Études sur la Méditerranée et le Moyen-Orient, Maison de l'Orient \\ Méditerranéen, Lyon, France. \\ *** Bahrain National Museum, Ministry of Information, Kingdom of Bahrain
}

The recent discovery in Bahrain of an important Greek inscription, Inscription 1, offers valuable new information on the history of this island and of the Gulf. At this time, it seems to us opportune to publish two previously unpublished Greek texts, Inscription 2 and Inscription 4, which, together with Inscription 3, another inscription already known but slightly corrected by a new reading, form a whole. These texts allow for a preliminary evaluation of the Greek epigraphy on Bahrain. All of the inscriptions presented here are housed in the Bahrain National Museum.

Inscription 1 : Dedicatory inscription in the name of king Hyspaosines and of queen Thalassia (Fig. 1)

Sandy limestone; a large block broken into three joining pieces. Dimensions : 49 x 98 x $10 \mathrm{~cm}$ minimum (the stone is currently set into a display case which does not permit a total appreciation of its thickness). Letters, 2-4 cm.

Very lightly engraved, very shallow letters ; alpha with a diagonal bar leaning towards the left; bridge shaped omega, fairly elongated ; kappa with a left stem separated from the rest of the letter. Squeeze (Institut Fernand Courby, Lyon).

Discovered in 1997 during the excavations by the Direction of Archaeology (Ministry of Information, Kingdom of Bahrain), this inscribed stone slab comes from Mound 1 at Shakhoura necropolis where it had been reused, upside down, as a covering slab of grave 40. This grave is clearly associated with Phase II of the cemetery, which is presently dated between the end of the first century BC and the beginning of the second century AD (1). Thus, several centuries may separate the carving of this inscription of its reuse as a slab.

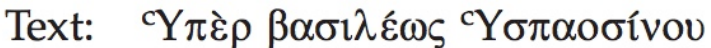

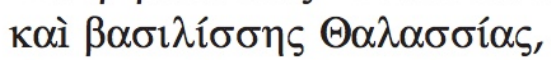

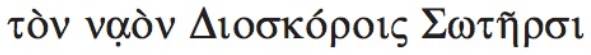

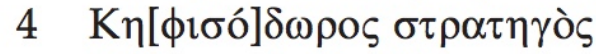

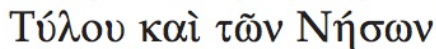

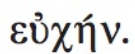


Translation: "In the name of King Hyspaosines and of Queen Thalassia, Kephisodoros, strategos of Tylos and of the Islands (has dedicated) the temple, to the Dioscuri Saviours, in exvoto ».

The text is a dedicatory inscription where the verb is implied. The dedicatory inscription is written «for» or « in the name» (2) of a king and a queen. It must have been placed inside of the dedicated monument itself, e.g. set into a wall of a naos, temple or chapel.

The ruler in question, Hyspaosines, who reigned over Bahrain when the text was engraved, was founder of the kingdom of Characene - also known as Mesene - and refounder of its capital Spasinou Charax «the rampart, fortress of Spasines (=Hyspaosines) », which had previously been called Alexandria, then Antioch, after former foundings by Alexander and an unidentified Seleucid sovereign (3). Three sets of documents inform us about Hyspaosines, first, brief allusions from classical authors, including Pliny and Lucian (4), second, Characenian coinage, which is coming increasingly well known (5); and third the late Babylonian astronomical diaries (6). We will summarize here his carreer.

According to Pliny, Hyspaosines would have been the son of a certain Sagdodonacos (7). We know nothing of the latter, but some scholars recognize him in the portrait of an aging man associated with Hyspaosines on certain of his bronze coins. It is probable that before assuming the royal title, Hyspaosines was first the satrap of the Seleucid province of the Erythraean Sea, even though Pliny only advances Juba's opinion on this point in order to reject it (8). The crisis which befell the Seleucid empire during the end of the second century BC gave him the opportunity to assume the royal title and declare his independence. The bronze coinage of Hyspaosines, depicted by himself or with an elderly male thought by some to be Sagdodonacos, is undated and has been the subject of much debate. We accept the opinion of G. Le Rider, who rejects the idea of the dating of two of these series - with Artemis and with Athena - to the period 141-139. The first dated coins of Hyspaosines are silver tetradrachms from 125/124 BC, on which Hyspaosines bears the title of king, and in Le Rider's opinion the bronze issues do not predate the silver ones (9). The Babylonian astronomical texts attest to military activity led by Hyspaosines in southern Mesopotamia between 138 and $132 \mathrm{BC}$, without allowing us to determine his precise relations with the Seleucids and the Parthians, at a time when other provinces, like Persis and Elymaiis, had already gained their independence. These same texts furnish the only two dates useful to the chronology of his carreer. One of the texts, from 127/126 B.C., mentions Hyspaosines, on June 24th 127 BC, giving him the title of king. This first evidence, coming from Babylon after it had been conquered by Hyspaosines, gives us a terminus ante quem. However, the two Babylonian texts from 138/137 and 133/132, which mention Hyspaosines without giving him the royal title, are not conclusive because Babylon was not at the time under his domination. Moreover another tablet specifies the day of the king's death, a date corresponding to June 11th 124 BC (10). It is evident that Hyspaosines' successors continued to mint coins in his name, several years after his death, since his silver coinage is known, uninterrupted, between 125/124 and 122/121 BC.

In sum, the Bahrain text must be dated from a period which would correspond to the years 140-124 BC if one extends the realm of possibility to its maximum. However, if one tries to narrow the time frame and imagines Hyspaosines as a cautions ruler pursuing a wait-and-see policy or indeed even as a faithful governor serving the Seleucids, then it was probably the failure of the expedition against the Parthians led by Antiochos VII Sidetes in 129 BC which would have enabled Hyspaosines to assume the royal title, thereby severing all ties with the Seleucids and playing his personal card (11).

The Babylonian astronomical texts contain another piece of information which the Greek inscription clarifies. The Babylonian text recording the death of Hyspaosines, although incomplete, appears to testify to a conflict between the king's wife, named Ta-la-si'asu and the leading citizens, the outcome of which enabled the queen to install her young son on the throne (12). The Bahrain inscription shows that in reality the queen bore the fairly rare Greek name of Thalassia (13). The 
association of the queen and king in the formulary is a well documented practice in numerous hellenistic monarchies (14).

Bahrain, as part of the newly created kingdom of Characene, was placed under the authority of a regional governor who probably resided on the large island, and who, according to the most traditional Hellenistic customs, bore the title of strategos (= satrap). The inscription reveals the existence of a strategy « of Tylos and the Islands ». The Greek name of Tylos, given to the large island, was well documented from the time of Alexander the Great onwards, beginning with Androsthenes of Thasos (15). "The Islands » almost certainly encompassed the archipelago surrounding Bahrain, but probably includes other islands in the Gulf as well (16). The strategos bears the Greek name Kephisodoros (17). It seems obvious that the Characene sovereignty on Bahrain and other islands of the Gulf was simply a continuation of the Seleucid domination on these same regions. The visit of the Seleucid king Antiochos III to Tylos during his eastern expedition must therefore be considered as a taking - or retaking - of control over the island. The Characenians preserved the territories, already part of the strategy-satrapy of the Erythraean Sea, and most probably never launched any attack from there, beyond the bounds of the former Seleucid territories. In all probability, Hyspaosines owes his success in establishing an independent kingdom to the naval capabilities of his province. Characene's rule throughout the Gulf was probably due to its commercial role and its navy. One should also remember that much later, in $131 \mathrm{AD}$, Tylos was still, or was perhaps once again, a dependancy of the Characene kingdom, with a « satrap of the Thilouanoi » in the service of « Meredat, king of Spasinou Charax » (18).

Kephisodoros dedicated a temple to the Dioscuri Saviours, a building of undetermined dimensions which may have only been a simple chapel. These Greek gods, the two brothers Castor and Pollux, are - among others things - the protectors of navigation and it is in this sense that they are described as "saviours »; in the Near East they also have "almost everywhere, until the end of the Hellenistic period, an official, royal and Greco-Macedonian character (19) », given to them first by the Seleucid and later perpetuated by the Parthians and the Greco-Bactrians. The temple must have been located close to the Shakhoura necropolis and most likely close to a harbour as well. Such a location could actually correspond to the site of Qal'at al-Bahrain, less than $3 \mathrm{~km}$ distant from Shakhoura and very probably the principal ancient harbour of the island. In addition, it is thus far the only settlement known on Bahrain for the Tylos period, the archaeology of which is otherwise attested only by its very numerous cemeteries. Knowledge of the levels attributed to this phase remains, nonetheless, limited at Qal'at al-Bahrain where they comprise part of a stratigraphic sequence nearly $8 \mathrm{~m}$ thick, which extends from the end of the third millenium BC to the Middle Islamic period (20).

Let us summarise the considerable contribution of Inscription 1 to the history of the Gulf. It is clear that the Seleucid empire, during the second century $\mathrm{BC}$, included a province of the Erythraean Sea, the capital of which was a Greek city in Southern Mesopotamia, Alexandria/Antioch, the future Spasinou Charax. It controled more or less distant possessions, including Failaka and Bahrain (21). Under the direction of the strategos (satrap) Hyspaosines, this province became the kingdom of Characene (Mesene) enjoying a dominant position in the Gulf as a maritime power. Hyspaosines, the kindom's founder, bore an iranian name even though his subjects were probably mainly Arabs (22), and was a former Seleucid civil servant and an Hellenistic prince. The monetary portrait of the king, represented in the Greek fashion and crowned with a diadem, followed the tradition of other dynasts of the same period, e.g. Kamniskires of Elymaïs and Tigraios of Susa, and of course the Parthians (23). Inscription 1 shows this attachment to Hellenism, as much by the use of Greek language and the traditional Hellenistic formulary as by the onomastics of the queen and the strategos and by the cult dedicated to the Greek gods of navigation. 
Inscription 2 : Burial inscription (Fig. 2-3)

This anthropomorphic stone burial stela from the Shakhoura necropolis belongs to a type well known both on Bahrain and on nearby Tarut (24). It is carved in local sandy limestone and is formed of a parallelepipedic pedestal topped by a central piece, tighter near the middle and wider towards the top, thus forming shoulders. This central part is topped by an oval summit-piece in the form of a head.

Sandy limestone. Complete. Dimensions : 41 x 19 (base) x $13 \mathrm{~cm}$. Letters, 1-2 cm. Moon-shaped sigma and epsilon; alpha either with broken bar or with diagonal bar; letters very finely engraved. Squeeze (Institut Fernand Courby, Lyon).

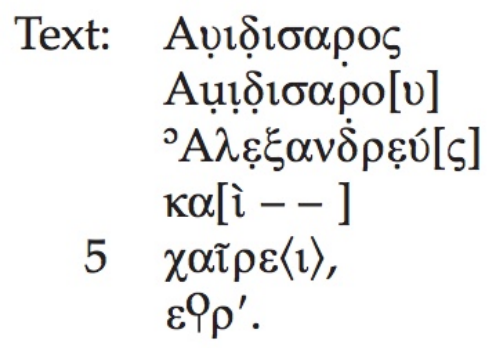

Critical notes : the wear of the material and the thinness of the engraving do not allow for an easy reading. Line 3 , the epsilon and the $x i$ touch each other; the letter following the rho ressembles more a moon-shaped epsilon than an omicron, with a strong opening of the arc, but one cannot completely rule out the reading 'A $A \varepsilon \xi \hat{\alpha} v \delta \rho o v$. Line 5, the sixth sign is clearly a stem, we correct to $\chi \alpha \tilde{1} \rho \varepsilon\langle\mathrm{\iota}\rangle$.

Translation : «Auidisaros son of Auidisaros, of Alexandria (?), and ... farewell. (The year) $195 »$.

This text presents numerous difficulties and its interpretation demands great caution. The clearest and most readable element is the date in the sixth line. As G. Le Rider has shown, the Characenians used the Seleucid era with a Macedonian computation, the starting date being the first day of the month of Dios, which corresponds to the beginning of the autumn of 312 BC (25). Therefore the burial inscription was engraved in 118/117, at a time when Hyspaosines (deceased in 124) had been replaced on the Characenian throne; we do not know the exact situtation of the kingdom before king Apodakos, whose coinage is dated to between 110/109 and 104/103, came to power, but it is generally thought that Apodakos could have been the young son that had been installed on the throne by the queen (Thalassia) as early as 124 (26). However, it would be unwise to over-interpret our inscription, which simply testifies to the presence and death in Bahrain of a greek-speaking person during this poorly known period.

Nevertheless, if our reading of the third line is correct - bearing in mind the difficulties with the text - the deceased would be an Alexandrian. His Semitic name and the absence of additional information beside the eventual ethnicon, push us to favour, among the numerous Alexandrias possible - including the Egyptian one - Alexandria-on-the-Erythraean Sea. There are two obvious conclusions to be drawn. On the one hand, this would show that Alexandria, the ancient name of Spasinou Charax was retained and that the later name of Antioch - too closely associated with the faltering Seleucid dynasty - and Spasinou Charax - too recent and not sufficiently prestigious - were considered irrelevant. On the other hand, if this interpretation is correct, it suggests the continuity of the relations, at least on an economic level, between Tylos and Characene (27).

The interpretation of the deceased's name demands great care since the reading is not clear. In this name, Auidisaros, the divine element is almost certainly the little known deity 'Ishr (found 
mainly at Hatra although occasionally elsewhere) in what, given the vowelling, must be an imperative sentence with the Semitic root ' $w d h$ «to protect», thus 'Awwidh-'Ishar, i.e. 'Ishar protect [me] (28).

\section{Inscription 3 : Burial inscription (Figs. 4-5)}

From the necropolis situated between Qal'at al-Bahrain and Karranah, found re-used in the construction of the walls of a cist-grave, comes this anthropomorphic stela - with broad shoulders on a waisted body - which was carved from the local sandy limestone. It is very similar to the stela bearing Inscription 2, but it has no pedestal. In its place is a prominent tenon destined to be driven into a separate base through a mortice.

Sandy limestone. Complete. Dimensions : $69.5 \times 19.5 \times 15.5 \mathrm{~cm}$. Letters 1-2 cm. Squeeze (J. MarcilletJaubert, Institut Fernand Courby, Lyon).

Published by J. Marcillet-Jaubert, 1990 (29). Checked again at the Bahrain National Museum (protected inside of a showcase).

\section{Text: $\quad \mathrm{A} \beta 1 \delta 1 \sigma \tau \alpha \rho \alpha \varsigma$ $\mathrm{A} \beta \delta \alpha \underline{\mathrm{c}} \mathrm{Ov}$ $\kappa v \beta \varepsilon \rho v \eta і \tau \eta \varsigma$ \\ $4 \quad$.. KִP $\Lambda[\cdot] \mathrm{EII}$ $\chi \alpha \tilde{\tau} \rho \varepsilon$.}

Critical notes : Our reading does not make significant progress in the deciphering of line 4,

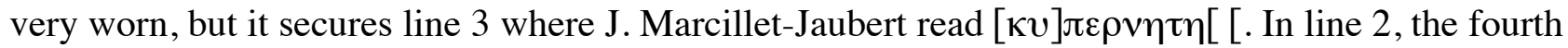
letter is a iota or a rho. In line 4, J. Marcillet-Jaubert reads [.][!!

Translation : «Abidistaras, son of Abdaios, captain (of vessel) ... farewell ».

Marcillet-Jaubert analysed the onomastics with for the two names the root " $b d$, "servant". The first is a theophoric name of Ishtar. The names are Semitic, the first perhaps "Babylonian". The profession of the deceased -a sailor, since the $\kappa v \beta \varepsilon \rho v \eta \tau \eta \varsigma$ both pilot and captain of a vessel (30)-, points once again towards Characene (Mesene). The writing, similar to that of Inscription 2 but with square or angular letters, has a slightly older, more polished style. We will date it also to the second half of the second century BC, noting the great similarity between the two stelae.

\section{Inscription 4 : Fragment (Fig. 6)}

Fragment of a parallelepipedic block from Qal'at al-Bahrain. Right side; the upper right angle is intact, the right lower angle is broken. However, the total height of the block is maintained. The number of preserved lines, only four, does not exclude the possibility of a shorter fifth line underneath. The remains of a raised border are preserved on the top. 


\section{Text: $[---] \mathrm{O} \Sigma \Pi \mathrm{MO} \Sigma \mathrm{TA}$ \\ $[---]$ OY $\Sigma T H N \Theta Y$ \\ $[---] \Delta \mathrm{OT} \Omega \mathrm{IK} Y$ \\ $4[---] \Sigma \Omega \Theta E N T O \Sigma$ \\ $[---]$}

Critical notes: The remains of the first visible letter of the first line belong to an epsilon or an omicron. The third letter of the first line is a pi with a left stem which has not been engraved.

This incription, although small (even though its total width remains undetermined), does not give the impression of being a burial inscription but rather a dedicatory or ex-voto text. Given the difficulty of evaluating the width of the missing section, which cannot be less than twice the size of the preserved part, we should be very careful in our interpretations.

Line 1-2: the remaining letters could suggest the restoration

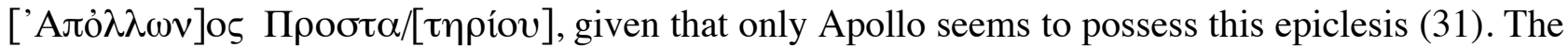
use of the genitive case is not suitable for designating the divinity to whom the offering is made, whose name should be in the dative case. One should therefore restore, in the missing part of line 1, the name of a person in the nominative case, with or without its patronym, and a religious title, such

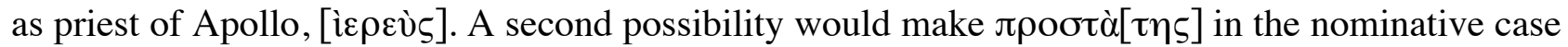
the title of the person named in the missing portion of the first line (32), preceded by the patronym ending in -05 .

Lines 2-3 : here again two possibilities are to be considered. The first visible letters - ous could be the genitive of a feminine name with a nominative ending in $-\omega$. One could also interpret

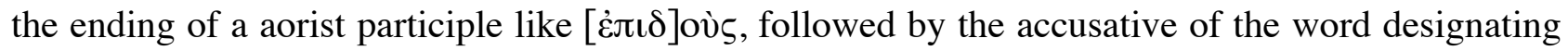
the offering, such as $\tau \dot{\eta} v \theta \dot{v} /[\rho \alpha \nu]$. The restoration $\tau \grave{\eta} \nu \theta v[\gamma \alpha \tau \dot{\varepsilon} \rho \alpha]$ would complicate the understanding of what precedes it.

Lines 3-4 : it seems to us that the first five visible letters cannot be anything else than the end of a proper name in the dative case, of the category of theophoric names such as Diodotos, Asclepiodotos, Isidotos, etc. The following two letters could be the beginning of a patronym, such as Kyrillos, Kyros, etc.; they could also represent the beginning of an ethnicon, such as Kvл $\rho$

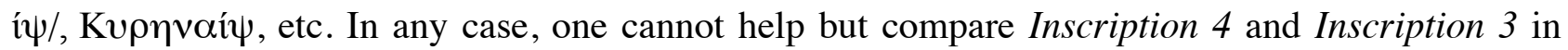

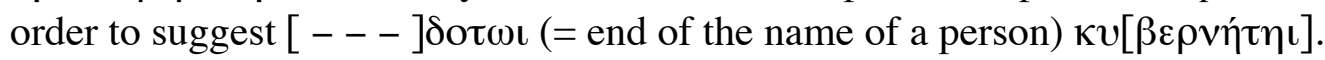

Line 4 : the aorist passive participle $\sigma \omega \theta \dot{\varepsilon} \mathrm{VTOS}$, in the genitive case could be an absolute genitive expressing a cause. The offering could have been made «because someone (one of the individuals mentionned in the inscription or a parent) has returned safe and sound » (33).

Line 5 : it is very likely that the inscription did not end at line 4 . It is perhaps here that the name of the divinity to whom the offering is being made should be placed, if, as seems plausible, the donor is mentionned in the first line. A verb like àvé $\theta \eta \kappa \varepsilon v$ could be restored, either in the first lines or here.

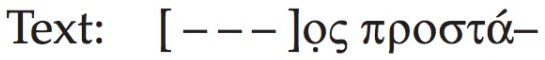

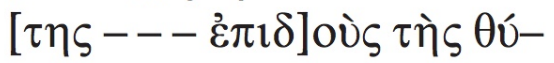

$$
\begin{aligned}
& {[\rho \alpha v---\sigma \grave{v} v--] \delta o ́ \tau \omega \mathrm{l} \kappa v-} \\
& 4[\beta \varepsilon \rho v \eta ́ \tau \eta 1---] \sigma \omega \theta \dot{\varepsilon} \vee \tau о \varsigma \\
& \text { [--- ]. }
\end{aligned}
$$

In the end, even if one can suggest several hypotheses, the only word complete and certain is that of line 4 , showing that the dedicatory inscription had probably been made following the safe 
and sound return of a person. The - hypothetical - comparison with Inscriptions 1 and 3 would suggest a maritime context for Inscription 4.

The date of this text can only be approximate, based on the writing style. Elements permitting comparison are rare in the region. However, by linking this inscription to those of Doura (34) or Susa, two Hellenized cities in the Parthian empire, we can suggest a date in to the period between roughly the second half of the second century $\mathrm{BC}$ and 130 or $140 \mathrm{AD}$, with a preference to the first century BC.

\section{Conclusion}

It is necessary to associate these four inscriptions from Bahrain with three objects inscribed in Greek. In one sense these are of less significance since nothing suggest that they were made on the island. However, their presence testifies to exchanges and to a certain use of the Greek language. The first is a glazed flask (35), decorated with the Greek alphabet, which is supposed to come from the al-Maqsha cemetery. The second is a bronze plate bearing the figure of Asclepios (36), the healing god whose name appears next to the his representation. Finally, the third is a potsherd, inscribed after firing, which contains only the end of a word - very likely an anthroponym (37) - and was found at Qal'at al-Bahrain. Even more significant than this modest evidence, is a burial headstone inscribed in Greek from the island of Tarut, although it is of a different type than the anthropomorphic stelae found previously in Bahrain and Tarut (38).

Beyond the capital importance of Inscription 1 for the political history of the Gulf (39), the other Greek inscriptions show that Tylos was a stopping point for people as well as a homeland for others who understood and used the Greek language, even though their semitic names suggest that they were not « Greeks ».

\section{REFERENCES}

1. We would like to express our thanks to those who have willingly shared their advice with us, especially Georges Rougemont (Lyon), Jean-François Salles (Lyon) and Françoise BriquelChatonnet (Paris). Concerning this necropolis, Al-Sindi Kh. and Ibrahim M., "Une nécropole représentative des diverses phases de Tylos: le Mont 1 de Shakhoura », in : Lombard P., ed. Bahrë̈n, la civilisation des deux mers. Paris-Gand : Institut du monde arabe \& SDZ, 1999 : 156159.

2. Frequent usage ; for example Bernand É. Recueil des inscriptions grecques du Fayoum, 1. Leiden : Brill, 1975 : 16-22, $\mathrm{n}^{\circ} 1-2$.

3. Schuol M. Die Charakene, Ein mesopotamisches Königreich in hellenistisch-parthischer Zeit. Stuttgart : Oriens et Occidens, $1: 2000$.

\section{Schuol, Die Charakene : 90-145.}

5. Le Rider G. «Monnaies de Characène », Syria 36: 1959: 229-253 ; Noldeman S.A., «A Preliminary History of Characene » Berytus 13: 1960: 83-121; Le Rider G., Suse sous les Séleucides et les Parthes. Les trouvailles monétaires et l'histoire de la ville. Paris, Mémoires de la mission archéologique en Iran, 38 : 1965. Schuol, Die Charakene : 217-240. 
6. Sachs AJ \& Hunger H. Astronomical Diaries and Related Texts from Babylonia, 3, Diaries from 164 B.C. to 61 B.C. Wien: Österreichische Akademie der Wissenschaften, PhilosophischHistorische Klasse, Denkschriften 247 : 1996.

7. Pliny, Natural History 6, 139 ; Le Rider, Suse sous les Séleucides : 182, 388 ; Schuol, Die Charakene : 219.

8. Le Rider, Suse sous les Séleucides : 259.

9. Datation of two series in 141-139 BC, due - particularly - to the presence of the busts of Sagdodonacos, and to the comparison with the coins of Demetrios II, Bellinger AR, «Hyspaosines of Charax », Yale Classical Studies 8: 1942: 61-63 ; Nodelman, "A Preliminary History of Characene » : 87 ; Schuol, Die Charakene : 219, 292-293. Dating to 124-120 BC (then 125-121 $\mathrm{BC})$, by drawing a parallel between these bronze coins and the dated tetradrachmas, Le Rider, «Monnaies de Characène »: 231-232; insisting on the presence of the bearded busts of Hyspaosines and of Sagdodonacos, considered as dating from a later period than another serie of bronze coins, where Hyspaosines is clean-shaven, Le Rider, Suse sous les Séleucides : 181-182. On this question see Gatier P-L. "Une inscription hellénistique de Bahrein, Hyspaosines et Tylos ». BCH 126 : 2002 : in press.

10. Sacks \& Hunger, Astronomical Diaries, 3: 159-179, 217, 255, 261, 283 ; Schuol, Die Charakene : 27-40.

11. Will Éd. Histoire politique du monde hellénistique, 2. Nancy : Annales de l'Est 32 : 1982 : 413 416.

12. Sacks \& Hunger, Astronomical Diaries, 3 : 283 ; Schuol, Die Charakene : 40.

13. Numerous examples of the the masculine names Thalassios, Thalassius, Thalassis, with apparently a concentration in Northern Syria (Roman and Byzantine periods), but these are also found in inscriptions from Athens, Tarentum-Taranto, Tocheira (Fraser \& Matthews E., A Lexicon of Greek Personal Names, Oxford, vol. 1-3B, 1987-2000). On the other hand, the feminine name seems very rare (during the Roman period some examples are found in Rome, names of slaves).

14. Many examples; see, in Egypt, Bernand A. Les inscriptions grecques de Philae, 1, Époque ptolémaïque. Paris : Centre National de la recherche scientifique, 1969.

15. Bowersock GW. «Tylos and Tyre : Bahrain in the Graeco-Roman World». In Ali Al-Khalifa H \& Rice M. eds. Bahrain Through the Ages. The Archaeology. London-New York : KPI, 1986 : 399406. In general see, Potts DT. The Arabian Gulf in Antiquity, 2, Oxford : Clarendon Press, 1990 ; Salles J-F. «L'Arabie sans Alexandre », Topoi 2 : 1992 : 201-235 ; Salles J-F. «Le golfe arabopersique entre Séleucides et Maurya », Topoi 4, 2 : 1994 : 597-610.

16. Ptolemy, Geography, 6, 7, 47, cites five islands in the Gulf, 'A

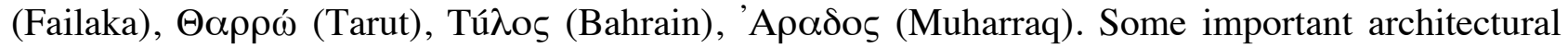
remains were found at Kharg. See also, among others Gulf islands, King G \& Tonghini C. «The western islands of Abu Dhabi Emirate, Notes on Ghagha' », in Philipps CS. et al. eds. Arabia and its Neighbours, Essays on prehistorical and historical developments presented in honour of Beatrice de Cardi. (Abiel 2), Brepols, Turnhout: 1998 : 117-142. Concerning Ichara-Ikaros (Failaka), Salles J-F. «Hellénisme et traditions orientales à Failaka », in Invernizzi A \& Salles J-F. eds. Arabia Antiqua, Hellenistic Centres around Arabia. Roma: Serie orientale Roma 70, 2: 1993 : 223-255. 
17. Several rivers in Greece and several god-rivers are named Kephisos, of which the most famous are those of Attica, Beotia and Argolis. One finds the name Kephisodoros most frequently in these areas. In the Near East, the name seems scarce.

18. Seyrig H. «Inscriptions grecques de l'agora de Palmyre », Syria 22: $1941: 252-255$ (=Antiquités syriennes, 3. Paris : Paul Geuthner : 1946: 196-199); Bowersock, "Tylos and Tyre $»: 405$.

19. Augé Ch \& Linant de Bellefond «P. Dioskouroi (in peripheria orientali)», in Lexicon iconographicum mythologiae classicae, 3, 1. Zürich-München : Artemis Verlag : 1986 : 593-597. On Failaka, a Greek inscription is a dedicatory inscription to Zeus Soter, to Poseidon and to Artemis Sôteira, very likely at the end of a voyage ; furthermore, the great inscription mentions, line 22, a saving god, Roueché Ch \& Sherwin-White M., "Some Aspects of the Seleucid Empire : the Greek Inscriptions from Failaka in the Persian Gulf », Chiron $15: 1985: 1-39$.

20. See Lombard P. \& Kervran M. «Les niveaux “ hellénistiques" du tell de Qal'at al-Bahrein. Données préliminaires », in Finkbeiner U. ed. Materialen zur Archäologie der Seleukiden- und Partherzeit im südlichen Babylonien und im Golfgebiet. Tübingen, Wasmuth 1993 : 127-160.

21. Roueché \& Sherwin-White, «Some Aspects » : 6-9, 30 ; Salles J-F. « The Arab-Persian Gulf under the Seleucids », in Kuhrt A \& Sherwin-White S. Hellenism in the East. Berkeley : University of California Press, 1987: 75-109. The province was certainly created before the reign of Antiochos III, at a date impossible to specify. Le Rider, Suse sous les Séleucides : 259.

22. Concerning the name of the king, Schuol, Die Charakene : 291-292. concerning the MeseniansCharacenians, Pliny, Natural History 6, 139, "Spaosines Sagdodonaci filius, rex finitimorum Arabum...".

23. Le Rider, Suse sous les Séleucides : 349-361, 379-386.

24. Stele "of the nefesh type" in Bahrein and Tarut, Marcillet-Jaubert J. « Stèle funéraire du Musée de Bahrein », Syria 67 : 1990 : 665-673 (voir 669-670, Salles J-F) ; Lombard P. « La sculpture : plâtre, terre cuite, pierre. », in Lombard P, ed. Bahreïn, la civilisation des deux mers : 204-216, see $146,155$.

25. Le Rider, Suse sous les Séleucides : 33-43.

26. Schuol, Die Charakene : 300-303.

27. King Apodakos of Characene minted bronze coins decorated with a ship's prow, which suggests that he had a naval policy. Le Rider, Suse sous les Séleucides: 407 ; Schuol, Die Charakene : 301-302.

28. We thank M.C.A. Macdonald for this information.

29. Marcillet-Jaubert, « Stèle funéraire du Musée de Bahrein » : 665-673.

30. Rougé J. La marine dans l'Antiquité. Paris : PUF, 1975 : 168.

31. Roscher WH. Ausführliches Lexikon der griechischen und römischen Mythologie, 3, 2. Leipzig : Teubner, 1902-1909 : col. 3150-3151 (Höfer). 
32. The meaning of this word is "head", "official", for example head of the priests of a sanctuary. Bernand, Recueil des inscriptions grecques du Fayoum, 1 : 31-34, 155-157.

33. Dittenberger W. Sylloge inscriptionum graecarum, Leipzig, Hirzelium $3: 1920: 291, \mathrm{n}^{\circ} 1130$; Robert J \& L. «Bulletin Épigraphique », Revue des Études grecques : 1969 : 525, n577.

34. Cumont F. Fouilles de Doura-Europos (1922-1923). Paris : Bibliothèque archéologique et historique, 9 : $1926: 415$ ( ${ }^{\circ} 61,19 / 20$ AD), 420 ( $\mathrm{n}^{\circ} 70,102 / 103$ AD), 422-423 ( ${ }^{\circ} 76,123$ AD), 434-435 ( $\left.\mathrm{n}^{\circ} 104,60 \mathrm{AD}\right)$, etc. See also pl. 113 ( ${ }^{\circ} 57-58,6$ BC). Concerning Suse, pers. comm. from G. Rougemont.

35. Lombard P. \& Kervran M. (eds) Bahrain National Museum, Archaeological collections Volume 1. A selection of pre-Islamic antiquities from excavations 1954-1975. Manama: Ministry of Information : 1989 : 99-100, $\mathrm{n}^{\circ}$ 172. Marcillet-Jaubert, «Stèle funéraire du Musée de Bahrein » : 670-672 (Salles).

36. Reproduced in Vine P. (ed.) Bahrain National Museum. London : Immel Publishing Ltd: $1993: 63$.

37. Marcillet-Jaubert, « Stèle funéraire du Musée de Bahrein » : 670-671 (Salles) ; Gatier P-L. « Un tesson inscrit en grec », in Højlund F \& Andersen HH. Qala'at al-Bahrain 1. Aarhus : Jutland Archaeological Society Publications, 30, $1: 1994: 317-318$. After a second reading of this potsherd (formerly published from a photograph) in the Bahrain Museum, it is now clear that the first preserved sign belongs in reality to a damaged letter. One must reads- therefore $[---] \Gamma$ PAIO $\Sigma$. This confirms that it is now most probably the end of an anthroponym. Tigraios could be the answer. Concerning the homonym who reigns in Susa towards 138-132 BC, see Le Rider, Suse sous les Séleucides : 81-83, 379-386. Of course there are few chances that it is the same person.

38. Jamme A. «The Pre-islamic Inscriptions », Oriens Antiquus 9 : 1970 : 132 ; Marcillet-Jaubert, «Stèle funéraire du Musée de Bahrein »: 666 (transcription); Potts, The Arabian Gulf: 51-53, pl. 3. The deceased bore a theophoric name related to Bel (Abeibel).

39. Between the arrival of Antiochos III in Tylos, during his eastern expedition (Polybius, Histories $13,9)$ and Hyspaosines, it is now clear that Tylos remained Seleucid, as was suggested by Salles, « The Arab-Persian Gulf under the Seleucids ». Later it became Characenian. The island's political situation is less clear during the preceding and following periods. Gatier, "Une inscription hellénistique de Bahrein : Hyspaosinès et Tylos ».

\section{CAPTIONS FOR FIGURES}

Figure 1:

\section{Inscription 1}

Figure 2 :

The burial stela, with the engraved text of Inscription 2

Figure 3 :

Inscription 2 
Figure 4 :

The burial stela, with the engraved text of Inscription 3

Figure 5 :

Inscription 3

Figure 6 :

Inscription 4

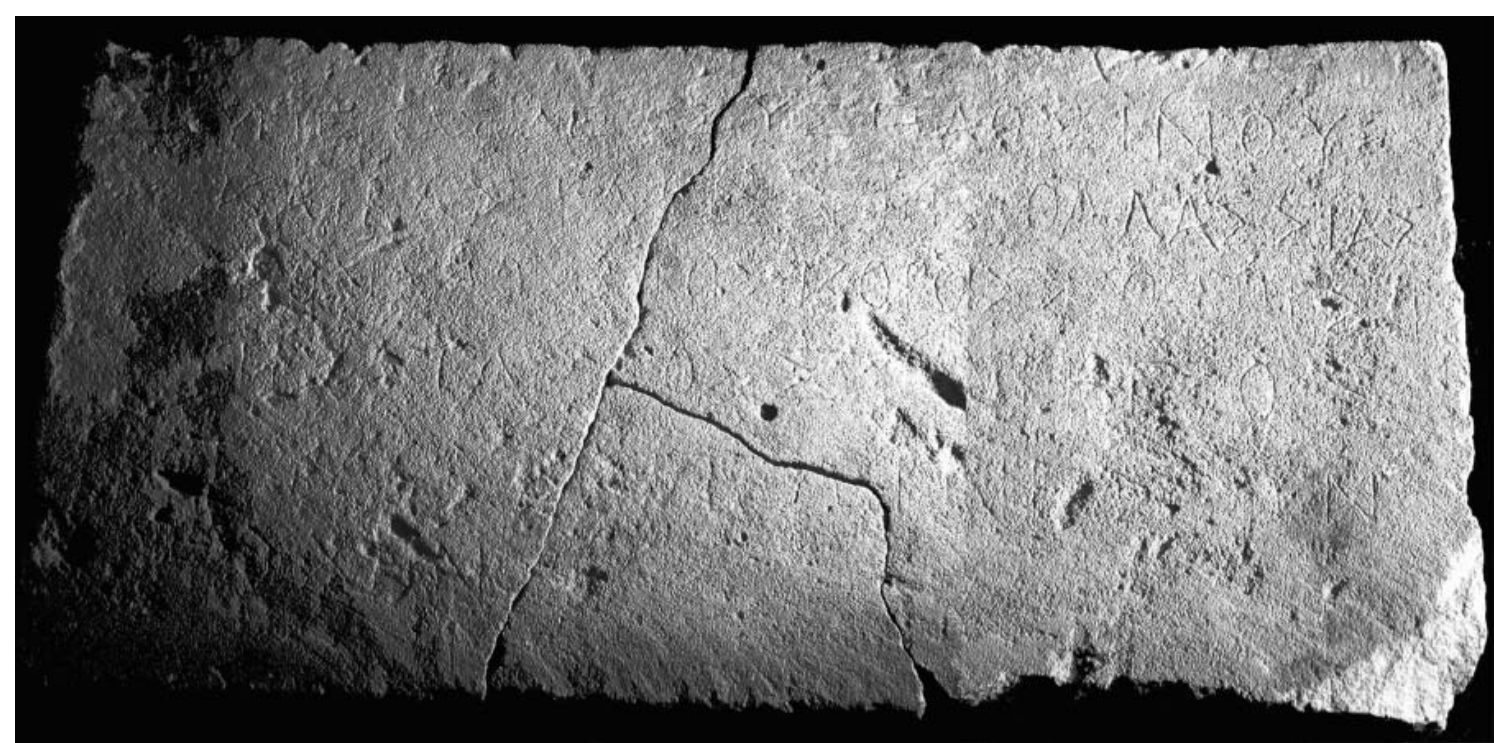

Figure 1
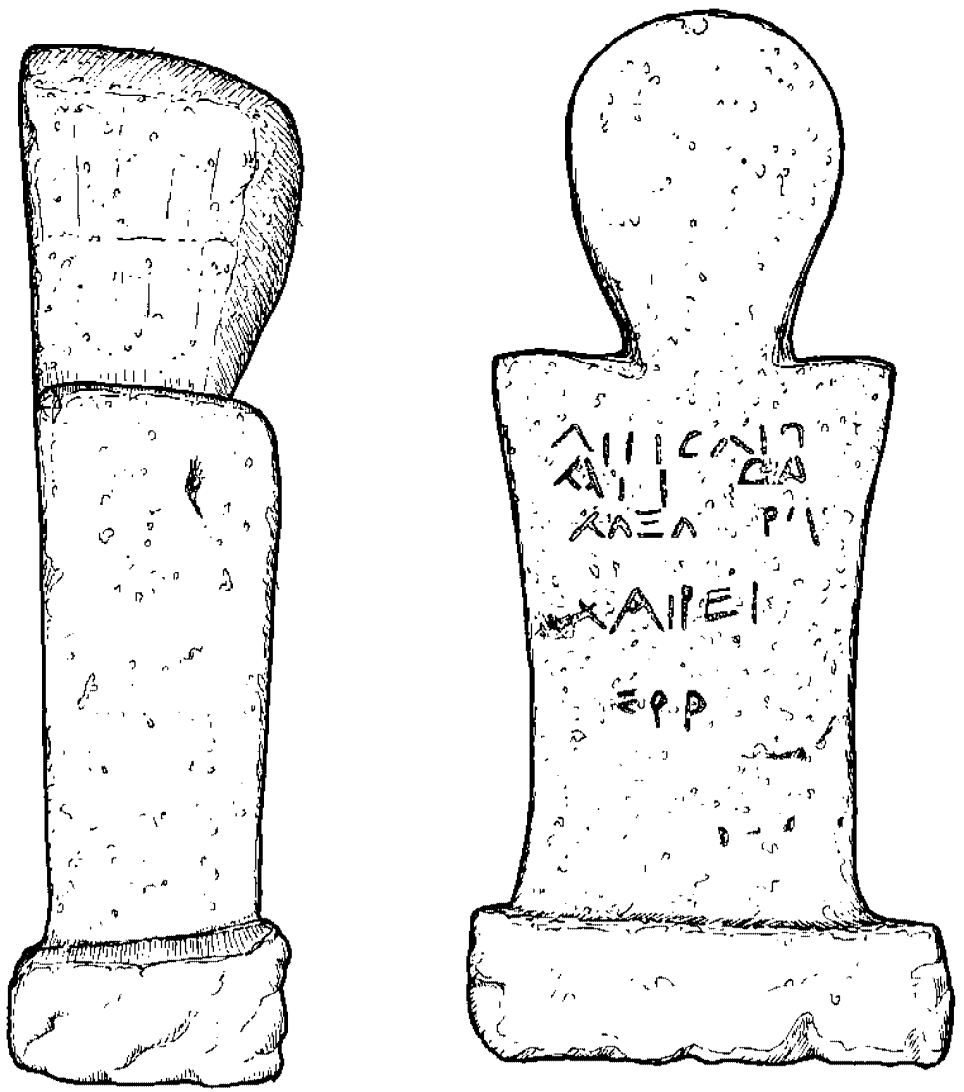

Figure 2 


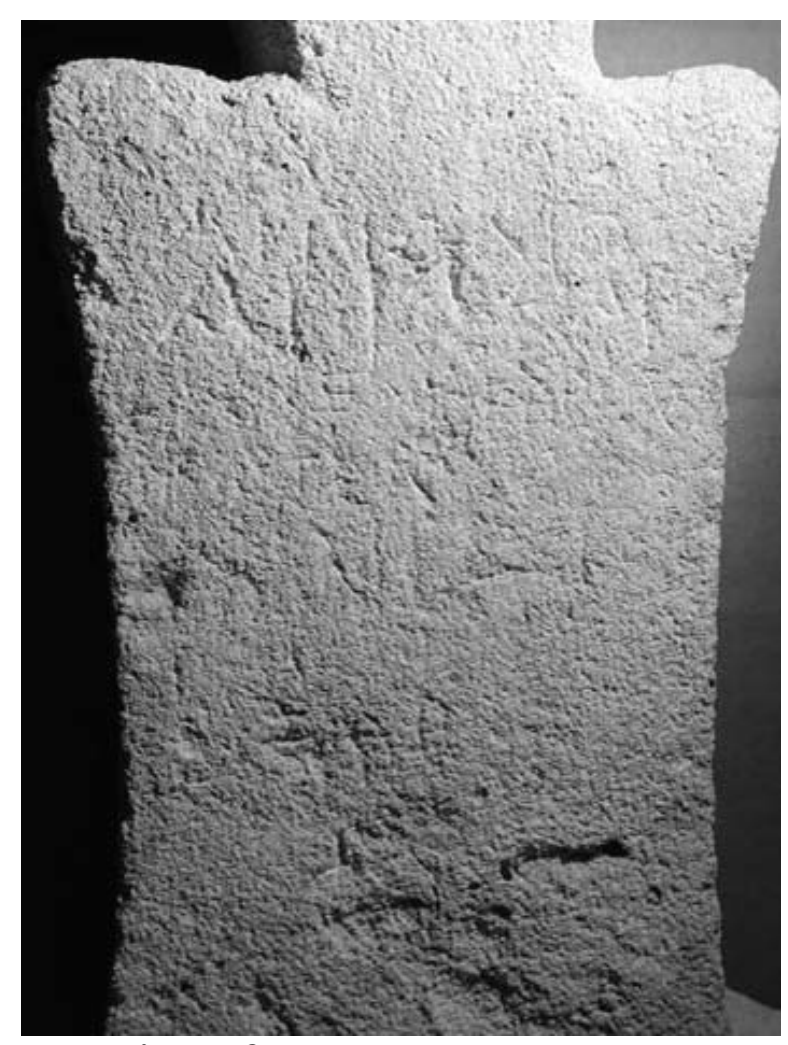

Figure 3

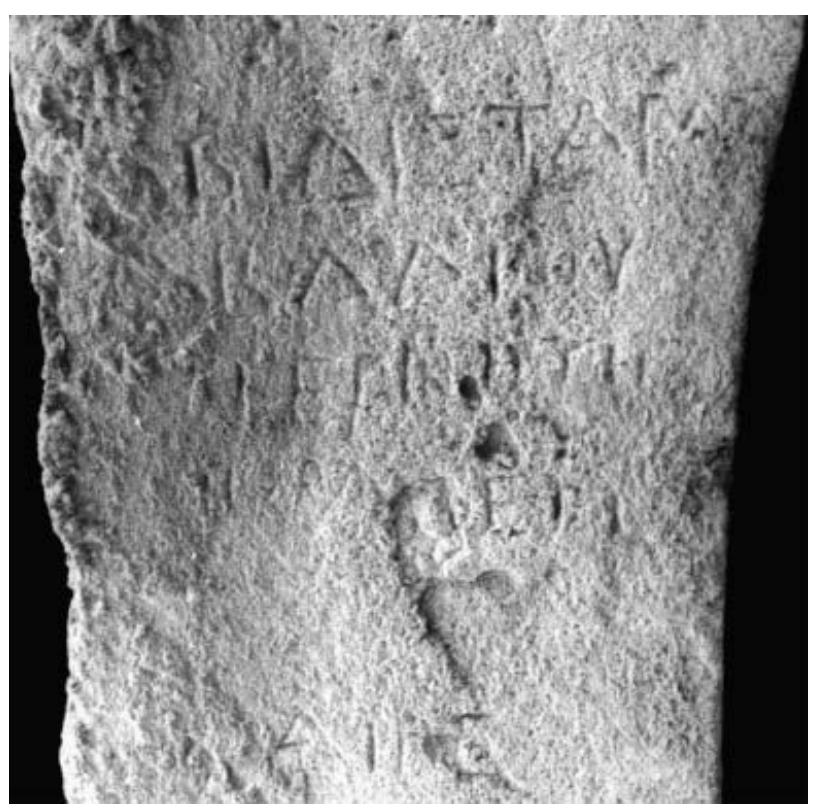

Figure 5

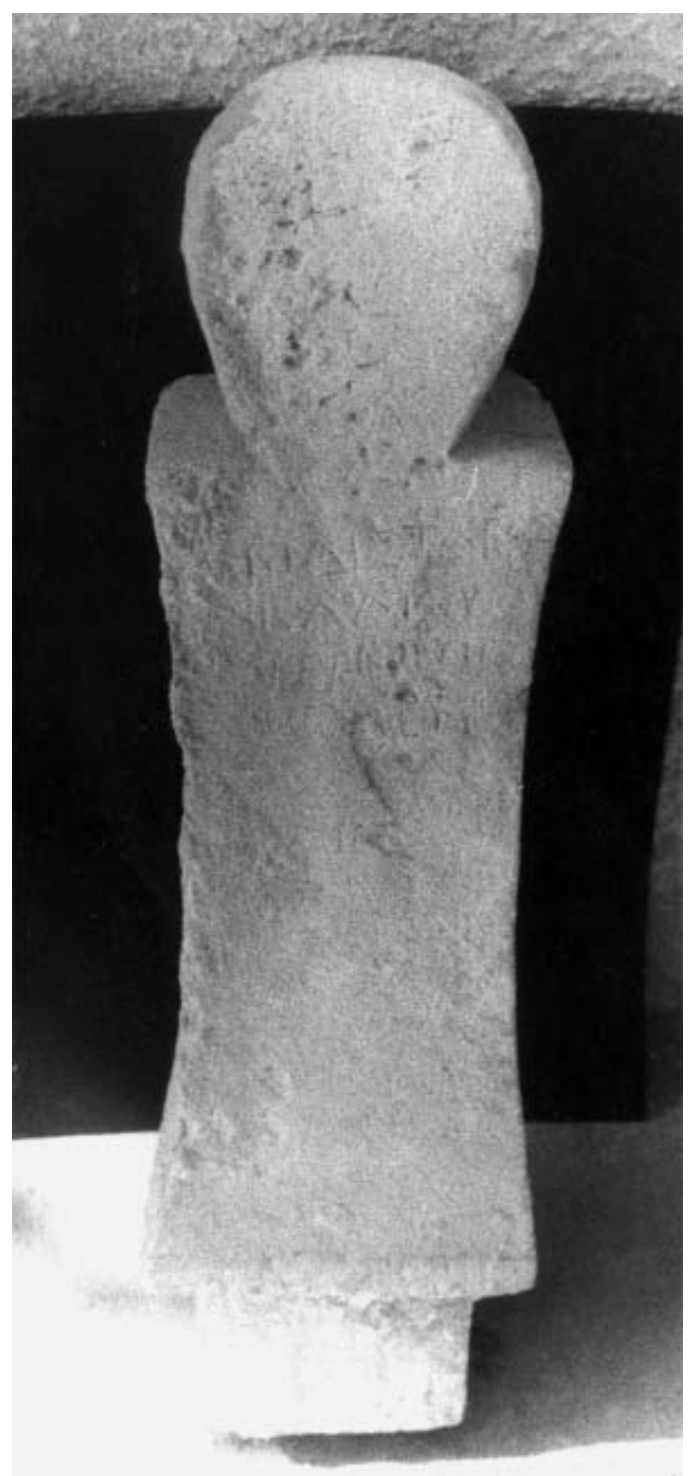

Figure 4

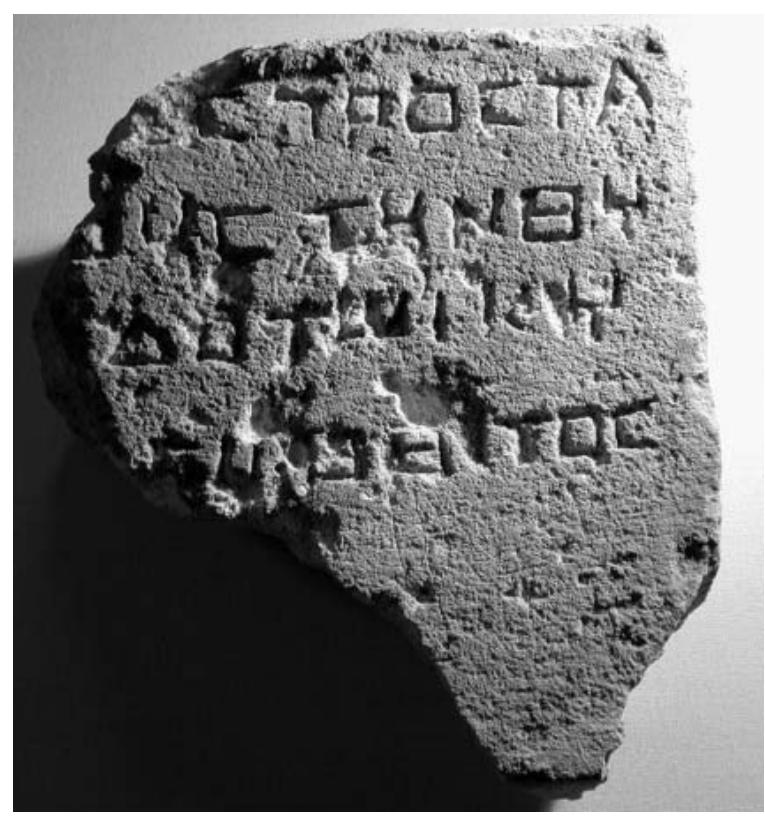

Figure 6 